\title{
WSPOMNIENIE O PROF. DR. HAB. GEORGU KOSSACKU
}

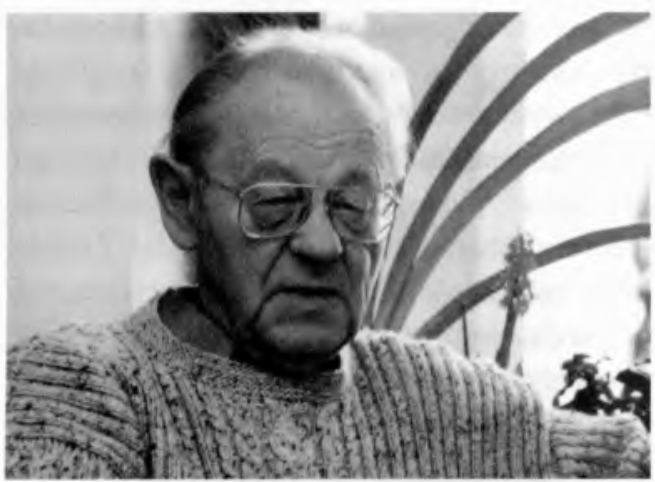

W dniu 17 października $2004 \mathrm{r}$. w bawarskim Prien zmarł w wieku 82 lat prof. dr hab. Georg Kossack, światowej sławy uczony, wybitna postać europejskiej archeologii.

Prof. dr hab. Georg Kossack urodził się 25 czerwca 1923 r. w brandenburskim Neuruppin. Mimo iż swą karierę naukową rozpoczął na Uniwersytecie w Marburgu, gdzie doktoryzował się w roku 1948 na podstawie pracy Studien zum Sym-

bolgut der Urnenfelder in der Hallstattzeit Mitteleuropas, opublikowanej w roku 1954, to jednak od początku najsilniej związany był z Bawarią i Uniwersytetem Ludwika Maksymiliana w Monachium, gdzie rozpoczał pracę na stanowisku asystenta. Efekty prowadzonych w tym czasie badań zaowocowały powstałą w roku 1955 praca habilitacyjną Südbayern während der Hallstettzeit, wydaną w 1959 r. w Berlinie. Po habilitacji nadal był związany z Instytutem für Vor- und Frühgeschichte w Monachium, w którym pracował jako docent do momentu, gdy w roku 1959 obejmował posadę profesora w Lehrstuhl für Vor- und Frühgeschichte Uniwersytetu Christiana Albrechta w Kilonii, przy czym związki naukowe prof. Georga Kossacka z południem Niemiec pozostawały nadal silne, czego świadectwem może być choćby opublikowana w 1970 r. rozprawa Gräberfelder der Hallstattzeit an Main und fränkischer Saale. Nie przeszkadzały mu one jednak w podjęciu zakrojonych na szeroką skalę prac badawczych poświęconych problematyce archeologii północnych Niemiec, co możemy dostrzec choćby na przykładzie takich prac, jak wydane w 1966 r. Beiträge zur Vor-und Frïhgechichte Mecklenburgs. Ein Forschungbericht, czy w książce z 1962 r.: Völker zwischen Germanen und Kelten. Schriftquellen, Bodenfunde und Namengut zur Geschichte des nördlichen Westdeutschlands um Christi Geburt, opublikowanej wraz z R. Hachmannem i H. Kühnem w Neumünster. Jednak szczególną pozycję zajmują tutaj zagadnienia związane z kwestiami osadniczymi w strefie wybrzeża Morza Pólnocnego, stanowiące do dzisiaj sztandarowe osiągnięcie niemieckich studiów osadniczych. Do tej problematyki prof. Georg Kossack powracał także w swych ostatnich publikacjach, czego przejawem może być wydana w $1997 \mathrm{r}$. w Monachium książka Dörfer im Nördlichen Germanien vornehmlich aus der römischen 
Kaiserzeit. Lage, Ortsplan, Betriebsfüge und Gemeinschaftsform. W roku 1975 powrócił ponownie na Uniwersytet w Monachium, gdzie objął stanowisko dyrektora instytutu; funkcję tę sprawował do roku 1988, w którym przeszedł na emeryturę. Moment ten nie zakończył jednak kariery naukowej i akademickiej Profesora. Nadal był aktywny zawodowo, prowadził w Inststitut für Vor- und Frühgeschichte und Prowinzionalrömische Archäologie Ludwig-Maximilians-Universität seminaria magisterskie oraz doktorskie, nieprzerwanie cały czas także uczestniczył w życiu naukowym.

W ramach swych zainteresowań badawczych prof. dr hab. Georg Kossack zajmował się przede wszystkim problemami wiążącymi się z epoką brązu oraz wczesną epoką żelaza, choć nieobca była mu również problematyka okresu przedrzymskiego, wpływów rzymskich i wczesnego średniowiecza. Dzięki swym szerokim horyzontom badawczym często wykraczał ponad czysto archeologiczne ramy naszej dziedziny wiedzy. Z wielkim powodzeniem prowadził Profesor badania interdyscyplinarne, wiążące się z problematyką religioznawcza, co znalazło odzwierciedlenie w Jego dysertacji doktorskiej. Zajmował się także badaniami struktur społecznych, ale przede wszystkim był prekursorem zakrojonych na szeroką skalę prac z dziedziny archeologii osadniczej, opartych na szerokiej bazie naukowej, ze szczególnym uwzględnieniem ekologii i paleobotaniki; zagadnienia te są tematem licznych Jego studiów, czego przykładem może być jego publikacja $\mathrm{z}$ roku 1984: Archäologische und naturwissenschaftliche Untersuchungen an ländlichen und frühstädtischen Siedlungen im deutschen Küstengebiet vom 5. Jahrhundert v. Chr. bis 11. Jahrhundert n. Chr. Na podstawie znalezisk archeologicznych prof. Georg Kossack starał się dociec, jak działalność ludzka w pradziejach wywierała wpływ na świat przyrody tak ożywionej, jak i nieożywionej. Z najważniejszych dla prahistorii prac Profesora wyłania się zarówno kompleksowe przedstawienie rolniczego trybu życia i podstaw gospodarczych społeczeństw żyjących w strefie wybrzeża Morza Północnego na tle współczesnego im ekosystemu, jak również obraz recepcji wpływów cywilizacji śródziemnomorskiej na jej północne peryferie. Nie będzie przesadą stwierdzenie, iż swą działalnością naukową prof. dr hab. Georg Kossack pobudzał liczne przełomy metodyczne $w$ archeologii.

Prof. dr hab. Georg Kossack działał w licznych organizacjach naukowych. W roku 1973 został członkiem korespondentem, a od roku 1979 członkiem zwyczajnym Oddziału Filozoficzno-Historycznego Bawarskiej Akademii Nauk, gdzie do końca przewodniczył Kommission zur vergleichenden Archäologie römischer Alpen und Donauländer. Profesor był także członkiem zwyczajnym Niemieckiego Instytutu Archeologicznego, członkiem korespondentem Fińskiego Stowarzyszenia Starożytności oraz członkiem zagranicznym Słoweńskiej Akademii Nauk i Sztuk.

Wspomnienie o prof. Georgu Kossacku byłoby niepełne, gdyby nie przypomnieć jego kontaktów z Instytutem Prahistorii UAM i zażyłej przyjaźni z wieloletnim dyrektorem tejże instytucji - prof. Janem Żakiem, zmarłym w 1990 r. Goszcząc w latach siedemdziesiątych w Poznaniu, prof. Georg Kossack wygłosił wykład poświęcony Kimmerom i ich wkładowi w rozwój cywilizacji epoki żelaza w Europie. Jego erudycja poruszyła ówczesnych słuchaczy. W trakcie swego pobytu odwiedził on także liczne 
stanowiska archeologiczne Wielkopolski; największe wrażenie wywarł na nim gród kultury łużyckiej w Biskupinie. Jego zdaniem ówczesne datowanie grodu na VI-V w. p.n.e. było zbyt późne i sugerował przesunięcie go na wiek VIII-VII p.n.e.; sugestie te ostatecznie potwierdzają najnowsze ustalenia badawcze. Także wśród niektórych materiałów z Biskupina dopatrywał się on już wówczas wpływów z kręgu jastorfskiego, co dopiero w kontekście najnowszego stanu wiedzy z ostatnich lat się potwierdza.

Prof. dr hab. Georg Kossack pozostawił po sobie nie tylko wybitne osiagnnięcia naukowe, ale także grono licznych uczniów i wychowanków, którym oprócz doskonałego warsztatu naukowego przekazał także swą miłość do archeologii.

Andrzej Michalowski

Instytut Prahistorii, Uniwersytet im. Adama Mickiewicza ul. Św. Marcin 78, 61-809 Poznań, Poland 